\title{
Influence of Plant Population Density on Growth and Yield of Lavender (Lavandula Anguistifolia L.) at Menagesha West Ethiopia
}

\author{
Nebret Tadesse \\ Wondo Genet Agricultural Research Center, EIAR, P.O. Box: 198, Shashemene, Ethiopia.
}

*Corresponding Author: Nebret Tadesse, Wondo Genet Agricultural Research Center, EIAR, P.O. Box: 198. Shashemene, Ethiopia.

\begin{abstract}
Field experiments were carried out during the two successive seasons of 2017 and 2018, at Menagesha Tisher rehabilitation center under supplementary irrigation condition. The aim of this investigation was to determine the effect of intra and inter-row spacing on growth and yield of lavender. Factorial combinations of four intra-rows $(40,50,60$, and $70 \mathrm{~cm})$ and three inter-row plant spacing's $(40 \mathrm{~cm}$, $60 \mathrm{~cm}$ and $80 \mathrm{~cm}$ ) were laid out in a randomized complete block design with three replications. The Pooled mean analysis result showed that the main effect of year, intra-row and inter-row spacing, as well as their interaction, were significantly affected, the number of branches per plant, leaf yield, flower yield, above ground biomass and oil yield. However, plant height was not affected by the main effect of intra -row and inter-row spacing except the year effect. Significantly higher dry leaf yield (2.34 tha-1), dry flower yield (0.37 t ha-1), dry flower oil yield (10.3 tha-1) and leaf oil yield (13.9t ha-1) were obtained from the combined space of $40 \mathrm{~cm}$ intra-row and 40 inter-row spacing. Thus the best combined intra-row and inter-row spacing for Lavandula angustifolia is $40 \mathrm{~cm} \times 40 \mathrm{~cm}$ to attain maximum yield under appropriate management conditions for Menagesha and Similar agro ecology.
\end{abstract}

Keywords: Lavandula angustifolia, intra-row, inter -row spacing, population density

\section{INTRODUCTION}

Lavandula angustifolia is a small, aromatic shrub belongs to the family Lamiaceae. Most lavender originates in the Mediterranean basin, in rocky, calcareous areas and Occurs over North Africa, the Mediterranean, Europe and Western India. Lavender was cultivated by the ancient Greeks, Romans and in Elizabethan England (Adam, 2006). It is an evergreen, fast growing, compact and fragrant. The origins of its name are probably from the Latin word Lavare indicating the plant has another use, as it means to be washed, and suggests it was regularly used to perfume bathing water (Whiriskey and McCarthy, 2006). It produces essential oil and the parts used for essential oil distillation are the flowers and leaves. An essential oil from only the flowering tops is of higher quality than oil obtained from the leaves (Adam, 2006)

Lavender is an incredible and much sought after aromatic plant having a significant position in the perfumery trade all over the world. It has multifarious uses and market outlets. Besides its use in fragrance applications, predominantly body care products, Lavender oil has substantial applications in alternative health care practices of aromatherapy (Chatterjee, 2002).

Pure oil can be used without base oil. It has a remarkable effect on the emotional and mental balance of human beings (Chatterjee, 2002). In addition, it is used in soap making, high-quality perfumes, candles, incense sachet, as a detergent and cleaning agent, as an insect repellent, and also used in bath products such as soap, shampoo, bath oil, lotion, bath salt, repel mice. Its powerful antiseptic properties are able to kill many of the frequent bacteria, such as typhoid, diphtheria, streptococcus and pneumococcus, as well as being a powerful antidote to some snake venoms. It is very useful in the treatment of burns, sunburn, scalds and bites (Chatterjee, 2002). The essential oil is used in aromatherapy and the leaves are also added to bath water for fragrance, and their therapeutic properties (Adam, 2006).

Plant spacing is agronomical practices that determine the spatial distribution of plants which affects canopy structure, light interception and radiation use efficiency and, consequently, biomass 
production of plants. Optimum plant density of variety considerably depending upon climatic condition of the growing area and fertility status of the soil is important.

Plant distant is an important factor in higher production and gives equal opportunity to plants for their survival and best use of other inputs. Spacing has critical effects on quantitative and qualitative characters of plants (Badi et al, 2004). To achieve the highest yield of economic production per unit area, crops should intercept solar radiation fully during the growing stage, in which photosynthesis provides carbohydrate for the economic products (Hall, 1990). In general, increasing a plant population produce a greater biological yield per unit area for most crops up to some upper limit or threshold density, after which further increase in plant density either maintain the same yield or cause yield decline. Hence it seems that plant geometry could be used as a management tool for maximizing crop growth and yield, so it is advisable to carry out trial in each plant to establish adequate plant population density. Therefore, in Ethiopia on the effect of intra-row and inter-row spacing on growth parameters, oil content and oil yield of lavender have not been yet reported. Therefore, this investigation was initiated with the objective of to determine optimum plant population density of growth and oil yield of Lavandula angustifolia in Ethiopia condition.

\section{MATERIAL AND MethodS}

The experiment was carried out under supplementary irrigated condition at Menagesha Rehabilitation Center- Cheshire Ethiopia during two successive seasons of 2016/17 and 2017/18. Menagesha Rehabilitation Center-Cheshire is located $20 \mathrm{~km}$ west of Addis Ababa at $09^{\circ} 03^{\prime} \mathrm{N}$ latitude and $38^{\circ} 34^{\prime}$ 60 ' $E$ longitude with an altitude of 2812 masl. The site receives a mean annual rainfall of $1056 \mathrm{~mm}$ with minimum and maximum temperature of $6{ }^{\circ} \mathrm{C}$ and $22^{\circ} \mathrm{C}$, respectively. The soil is clay with an average $\mathrm{pH}$ of 5.4. The experiment was conducted on Lavandula Angustifolia using four intra-row spacing $(40 \mathrm{~cm}, 50 \mathrm{~cm}, 60 \mathrm{~cm}$ and $70 \mathrm{~cm})$ and three inter-row spacing $(40 \mathrm{~cm}, 60 \mathrm{~cm}$ and $80 \mathrm{~cm})$ that were laid out in a factorial randomized completely block design ( RCBD) with three replications. Each treatment had a plot size of $4.20 \mathrm{~m} \times 3.60 \mathrm{~m}$ and spaces between each plot and replication were $1 \mathrm{~m}$ and $1.5 \mathrm{~m}$ respectively. The number of plants per row and the number of row per plot were determined by intra and inter-row spacing respectively. Soft stem cutting with $15 \mathrm{~cm}$ length were taken from a one year old disease free mother plants maintained at Wondo Genet Agricultural Research Center botanical garden in seedling preparation. Seedlings were raised in the nursery for three months in polyethylene pots before transplanting to the actual field. First cycle harvesting was done seven months after transplanting, consecutively, second cycle harvestings were done at seven month intervals. During experimentation, all nursery and field agronomic practices were performed as required.

\subsection{Data to be Collected}

Plants from the center were harvested by excluding border rows to collect yield and yield contributing characters on plant height, fresh leaf weight plant ${ }^{-1}$, number branch plant ${ }^{-1}$, flower weight plant ${ }^{-1}$, fresh stem weight, above ground biomass plant $^{-1}$, were recorded during each harvesting cycle. Essential oil content and essential oil yield were determined by taking $300 \mathrm{~g}$ of fresh leaves and flowers from composite samples harvested from three middle rows of a plot. Essential oil extraction was done using a hydro-distillation method in a Clevenger apparatus. Experimental data were subjected to analysis of variance (ANOVA) using SAS PROC GLM at $P<0.05$. Differences between means were assessed using the least significant difference (LSD) test.

\section{RESULT AND DISCUSSION}

\subsection{Number of Primary Branches Per Plant and Plant Height (cm)}

Pooled mean analysis of variances showed that the main effect of year, intra-row and inter-row spacing, and interaction year with intra and inter-row spacing were significantly $(\mathrm{p}<0.05)$ affect the number of branches per plant (Table 1). However, intra-row with inter-row interaction was not significant. Maximum number of primary branches per plant (100.5) and (95.9) were obtained from 70 intra-row and 80inter-row spacing in second year this attribute to the effect of first year harvesting (pruning) that may contribute to the lateral growth of the branch. The lowest number of primary branches per plant (42.6) and (42.3) were recorded from the narrow spacing of $40 \mathrm{~cm}$ intra-row and $40 \mathrm{~cm}$ inter-row spacing in the first year. In the second year harvesting the wider spacing with the some intra-row $58.6 \%$ number of primary branch increments was recorded (Table 3). The higher 
Influence of Plant Population Density on Growth and Yield of Lavender (Lavandula Anguistifolia L.) at Menagesha West Ethiopia

number of branches per plant in the wider intra-row and inter-row spacing with plant age might be due to the age of the plant and more availability of growth factors, better penetration of light, consequently, increasing the number of leaves and branch production at wider row spacing.

Table1. Pooled means analysis of variance influence of plant population density on yield and yield component of Lavandula Angustifolia at Menagesha

\begin{tabular}{|c|c|c|c|c|c|c|c|c|c|}
\hline Mean square & DF & PH & NBPP & FWPH & DFWPH & DLWPH & AGDB & FOY & LOY \\
\hline Replication & 2 & $271.4^{*}$ & $211.5 \mathrm{~ns}$ & $0.041 \mathrm{~ns}$ & $0.004 \mathrm{~ns}$ & $0.055 \mathrm{~ns}$ & $0.77 \mathrm{~ns}$ & 11.56 & $5.62 \mathrm{~ns}$ \\
\hline Years & 1 & $5006.7^{*}$ & $37688.8^{* *}$ & $0.269^{*}$ & $0.026^{*}$ & $2.115^{* *}$ & $14.63^{* *}$ & $12.2 \mathrm{~ns}$ & $147.3^{*}$ \\
\hline Inter-row & 2 & $1.9 \mathrm{~ns}$ & $187.1^{*}$ & $0.859^{* *}$ & $0.086^{* *}$ & $4.029^{*}$ & $14.51^{* *}$ & $48.6^{*}$ & $330.4^{* *}$ \\
\hline Intra-row & 3 & $44.2 \mathrm{~ns}$ & $398.6^{*}$ & $0.408^{*}$ & $0.030^{* *}$ & $1.978^{*}$ & $11.33^{* *}$ & $32.71^{*}$ & $110.4^{*}$ \\
\hline Year*intra & 3 & $7.01 \mathrm{~ns}$ & $393.9^{*}$ & $0.061 \mathrm{~ns}$ & $0.005 \mathrm{~ns}$ & $0.052 \mathrm{~ns}$ & $1.650 \mathrm{~ns}$ & $2.90 \mathrm{~ns}$ & $2.149 \mathrm{~ns}$ \\
\hline Year*inter & 2 & $101.97^{*}$ & $440.6^{*}$ & $0.111^{*}$ & $0.010^{*}$ & $0.029^{*}$ & $0.984 \mathrm{~ns}$ & $8.08 \mathrm{~ns}$ & $0.67 \mathrm{~ns}$ \\
\hline Intra*Inter & 6 & $48.2 \mathrm{~ns}$ & $92.9 \mathrm{~ns}$ & $0.097^{*}$ & $0.011^{*}$ & $0.186^{*}$ & $1.23 \mathrm{~ns}$ & $17.04^{*}$ & $17.48 \mathrm{~ns}$ \\
\hline $\mathrm{Y}^{*}$ Intra*Inter & 6 & $50.8 \mathrm{~ns}$ & $178.6 \mathrm{~ns}$ & $0.038 \mathrm{~ns}$ & $0.003 \mathrm{~ns}$ & $0.055 \mathrm{~ns}$ & $0.909 \mathrm{~ns}$ & $2.45 \mathrm{~ns}$ & $2.73 \mathrm{~ns}$ \\
\hline Error & 46 & 31.0 & 111.3 & 0.031 & 0.003 & 0.056 & 0.695 & 4.30 & 19.9 \\
\hline CV\% & & 7.21 & 15.62 & 29.3 & 30.1 & 18.4 & 31.1 & 29.4 & 28.7 \\
\hline
\end{tabular}

$D F=$ Degree of freedom, $P H=$ plant height, NBPP= number of branches per plant, Number of flowers

The reduction in branch number per plants with deceasing intra and inter-row spacing may be due to greater inter-plant competition for incident light, soil nutrition, soil moisture and mutual shading of each other at a high plant density than at low plant density and the age of the plant.

This could be explained in such a way that, as plant spacing increased in both directions and year, ample resources become available for each plant that enhances the lateral vegetative growth of the crop. This finding is in line with the result of Tadesse et al. (2016) who reported higher branch number plant ${ }^{-1}$ at the wider spacing than the closest in Stevia. Similarly result was also reported by Beemnet et al. (2012) on Rose Scented Geranium (Pelargonium graveolens), Zewdinesh et al. (2011) on Artemisia (Artemisia annua L.).

Pooled mean analysis result showed that the main effect of intra-row and inter-row spacing and their interaction were not affected plant height of Lavandula angustifolia. However the Lavadula angustifolia plant height recorded during the experiment conducted were raged $75.3 \mathrm{~cm}$ to $79 \mathrm{~cm}$ and $75.5 \mathrm{~cm}$ to $77.1 \mathrm{~cm}$ height for intra-row and inter-row spacing respectively (Table 2 ).

Table2. Main effects of intra-row and inter-row spacing on yield and yield component of Lavandula angustifolia at Menagesha in the pooled mean analysis

\begin{tabular}{|c|c|c|c|c|c|}
\hline $\begin{array}{l}\text { Cropping } \\
\text { Years }\end{array}$ & $\begin{array}{l}\text { Number of primary } \\
\text { branches per plant }\end{array}$ & $\begin{array}{l}\text { Plant height } \\
\text { (cm) }\end{array}$ & $\begin{array}{l}\text { Above ground } \\
\text { biomass (t/ha) }\end{array}$ & $\begin{array}{c}\text { Flower Oil } \\
\text { yield }(\mathrm{kg} / \mathrm{ha})\end{array}$ & $\begin{array}{l}\text { Leaf Oil yield } \\
(\mathrm{kg} / \mathrm{ha})\end{array}$ \\
\hline $2016 / 17$ & $44.69 \mathrm{~b}$ & $85.59 \mathrm{a}$ & $2.24 b$ & 5.49 & $8.83 b$ \\
\hline $2017 / 18$ & $90.44 \mathrm{a}$ & $68.9 \mathrm{~b}$ & $3.14 \mathrm{a}$ & 4.67 & $11.69 \mathrm{a}$ \\
\hline LSD 0.05 & 5.0 & 2.64 & 0.39 & $\mathrm{Ns}$ & 2.11 \\
\hline \multicolumn{6}{|c|}{ Intra-row $(\mathrm{cm})$} \\
\hline 40 & $61.5 \mathrm{~b}$ & 77.87 & $3.8 \mathrm{a}$ & $7.0 \mathrm{a}$ & $13.5 \mathrm{a}$ \\
\hline 50 & $66.15 \mathrm{ab}$ & 76.78 & $2.6 \mathrm{~b}$ & $5.0 \mathrm{~b}$ & $10.9 \mathrm{ab}$ \\
\hline 60 & $71.01 \mathrm{a}$ & 79.0 & $2.4 b c$ & $4.3 \mathrm{~b}$ & $8.7 b c$ \\
\hline 70 & $71.5 \mathrm{a}$ & 75.3 & $1.89 \mathrm{c}$ & $4.0 \mathrm{~b}$ & $8.0 \mathrm{c}$ \\
\hline LSD & 7.1 & $\mathrm{Ns}$ & 0.56 & $1.4 *$ & 2.7 \\
\hline \multicolumn{6}{|c|}{ Inter-row $(\mathrm{cm})$} \\
\hline 40 & $62.5 b$ & 77.1 & $3.5 \mathrm{a}$ & $6.7 \mathrm{a}$ & $14.3 \mathrm{a}$ \\
\hline 60 & $69.2 \mathrm{a}$ & 76.1 & $2.7 \mathrm{~b}$ & $4.51 \mathrm{~b}$ & $9.6 \mathrm{~b}$ \\
\hline 80 & $71.0 \mathrm{a}$ & 75.5 & $1.9 \mathrm{c}$ & $4.04 \mathrm{~b}$ & $6.9 \mathrm{c}$ \\
\hline LSD 0.05 & 7.1 & Ns & 0.51 & $1.17 *$ & 2.35 \\
\hline $\begin{array}{l}\text { Intra } \\
\text { *Inter }\end{array}$ & Ns & Ns & ns & $*$ & ns \\
\hline $\mathrm{CV} \%$ & 17.9 & 3.9 & 23.7 & 29 & 27 \\
\hline
\end{tabular}

Means followed by the same letter within the same column are statistically no significant at $P<0.05$ according to least significant difference (LSD) test; 
Influence of Plant Population Density on Growth and Yield of Lavender (Lavandula Anguistifolia L.) at Menagesha West Ethiopia

Table3. Interaction effects intra-row, inter-row spacing with years on numbers of primary branch per plants

\begin{tabular}{|c|c|c|c|c|c|c|c|c|c|}
\hline \multirow{3}{*}{$\begin{array}{c}\text { Cropping } \\
\text { years }\end{array}$} & \multicolumn{9}{|c|}{ Number of primary branches per plant } \\
\hline & \multicolumn{5}{|c|}{ Intra-row spacing } & \multicolumn{4}{|c|}{ Inter-row spacing } \\
\hline & $40 \mathrm{~cm}$ & $50 \mathrm{~cm}$ & $60 \mathrm{~cm}$ & $70 \mathrm{~cm}$ & Mean & $40 \mathrm{~cm}$ & $60 \mathrm{~cm}$ & $80 \mathrm{~cm}$ & Mean \\
\hline $\begin{array}{c}2016 \\
\text { cropping }\end{array}$ & $42.59 \mathrm{~d}$ & $47.58 \mathrm{~d}$ & 47.0 & $41.58 \mathrm{~d}$ & 44.69 & $42.3 \mathrm{c}$ & $45.6 \mathrm{c}$ & $46.0 \mathrm{c}$ & 44.63 \\
\hline $\begin{array}{c}2017 \\
\text { cropping }\end{array}$ & $81.47 \mathrm{c}$ & $84.73 b c$ & $95.0 \mathrm{ab}$ & $100.5 \mathrm{a}$ & 90.43 & $82.65 b$ & $92.73 a$ & $95.9 \mathrm{a}$ & 90.43 \\
\hline Mean & 62.03 & 66.15 & 71 & 71.04 & & 62.48 & 69.17 & 70.95 & \\
\hline LSD 0.05 & \multicolumn{4}{|c|}{11.53} & & \multicolumn{4}{|c|}{9.99} \\
\hline $\mathrm{CV} \%$ & \multicolumn{4}{|c|}{17.5} & & \multicolumn{4}{|c|}{17.5} \\
\hline
\end{tabular}

Means followed by the same letter within the same rows are statistically no significant at $P<0.05$ according to least significant difference (LSD) test;

\subsection{Fresh Flower Yield $\left(\mathrm{t} \mathrm{ha}^{-1}\right)$ and Dry Flower Yield $\left(\mathrm{t} \mathrm{ha}^{-1}\right)$}

Pooled mean analysis result showed that the main effect of intra-row and inter-row spacing, were very highly significant $(\mathrm{P}<0.01)$ and the interaction effect of year with inter-row spacing, the interaction effect of intra-row with inter-row spacing were significantly $(\mathrm{P}<0.05)$ affected on fresh flower yield (Table 1). Significantly higher fresh flower yield was obtained in the second year than the first year with the same spacing. Highest fresh flower yield $\left(1.21 \mathrm{tha}^{-1}\right)$ was obtained from the combination spacing of $40 \times 40 \mathrm{~cm}$ intra-row and inter-row spacing respectively. Followed by fresh flower yield value obtained from the combined of $40 \mathrm{~cm}$ inter-row spacing with $50 \mathrm{~cm}$ intra-row, $60 \mathrm{~cm}$ intra-row, 70 intra-row spacing and $60 \mathrm{~cm}$ inter-row spacing with $40 \mathrm{~cm}$ intra-row spacing which were statistically similar with each other, however better than the rest of wider combined of intra-row and inter-row spacing. The lowest fresh flower yield $(0.343 \mathrm{t}$ ha-1) was recorded from the combined space of $70 \mathrm{~cm}$ intra-row and $80 \mathrm{~cm}$ inter-row, which was statically at par with a fresh flower yield obtained from the combined spacing of $60 \mathrm{~cm} \times 50 \mathrm{~cm}, 60 \mathrm{~cm} \times 70 \mathrm{~cm}, 80 \mathrm{~cm} \times 40 \mathrm{~cm}, 80 \mathrm{~cm} \times 50 \mathrm{~cm}, 80 \mathrm{~cm} \times 60 \mathrm{~cm}$ intrarow and inter-row spacing respectively (Table $4 \& 5$ ).

The interaction effect of intra and inter-row spacing showed significant $(\mathrm{p}<0.05)$ difference on dry flower yield $\mathrm{t} \mathrm{ha}^{-1}$ in the pooled mean analysis. Similar trend were observed with fresh flower yield; Maximum dry flower yield $\left(0.367 \mathrm{tha}^{-1}\right)$ was obtained from the combined spacing of $40 \mathrm{~cm}$ intra-row and $40 \mathrm{~cm}$ inter-row spacing followed by dry flower yield $\left(0.216 \mathrm{tha}^{-1}\right)$ obtained from the combined spacing of $40 \mathrm{~cm}$ intra-row and $60 \mathrm{~cm}$ inter-row spacing which were statistically similar with the value recorded from the combined spacing of $40 \mathrm{~cm}$ inter row with the intra row of $50 \mathrm{~cm}, 60 \mathrm{~cm}, 70 \mathrm{~cm}$ and $60 \mathrm{~cm}$ inter-row spacing with $50 \mathrm{~cm}, 60 \mathrm{~cm}$ intra-row spacing. The lowest dry flower yield $\left(109 \mathrm{t} \mathrm{ha}^{-1}\right)$ recorded from the combined spacing of $60 \mathrm{~cm}$ intra-row and $80 \mathrm{~cm}$ inter-row spacing. Increasing the spacing between plants and rows from $40 \times 40 \mathrm{~cm}$ to $60 \times 60 \mathrm{~cm}$ and $60 \times 80 \mathrm{~cm}$ intra-row and inter-row spacing resulted in 54.2\% and $70.3 \%$ decreased in dry flower yield ton per hectare of Lavender (Table 4). Increasing fresh flower dry flower yield per hectare was attributed to the accommodation of a number of plants at a closer spacing than in the wider spacing.

Table4. Pooled means for interaction effects of intra and inter-row spacing on fresh flower yield, dry flower yield, dry leaf yield $\left(\mathrm{t} \mathrm{ha} \mathrm{h}^{-1}\right)$ and flower oil yield $\left(\mathrm{kg} \mathrm{ha}^{-1}\right)$ of Lavandula angustifolia in 2016 and 2017 cropping season

\begin{tabular}{|cc|c|c|c|c|c|}
\hline $\begin{array}{c}\text { Inter-row } \\
(\mathrm{cm})\end{array}$ & $\begin{array}{c}\text { Intra-row( cm) } \\
\text { spacing }\end{array}$ & $\begin{array}{c}\text { Fresh Flower } \\
\text { yield }\left(\mathrm{t} \mathrm{ha}^{-1}\right)\end{array}$ & $\begin{array}{c}\text { Dry Flower } \\
\text { yield }\left(\mathrm{t} \mathrm{ha}^{-1}\right)\end{array}$ & $\begin{array}{c}\text { Dry leaf yield (t } \\
\left.\mathrm{ha}^{-1}\right)\end{array}$ & $\begin{array}{c}\text { Flower oil yield } \\
\left(\mathrm{kg} \mathrm{ha}^{-1}\right)\end{array}$ \\
\hline $40 \mathrm{~cm} \times \mathrm{x}$ & $40 \mathrm{~cm}$ & $1.21 \mathrm{a}$ & $0.37 \mathrm{a}$ & $2.34 \mathrm{a}$ & $10.28 \mathrm{a}$ \\
\hline $40 \mathrm{~cm}$ & $\mathrm{x}$ & $50 \mathrm{~cm}$ & $0.66 \mathrm{bc}$ & $0.21 \mathrm{~b}$ & $1.83 \mathrm{~b}$ & $6.44 \mathrm{~b}$ \\
\hline $40 \mathrm{~cm}$ & $\mathrm{x}$ & $60 \mathrm{~cm}$ & $0.69 \mathrm{bc}$ & $0.19 \mathrm{bc}$ & $1.57 \mathrm{~b}$ & $6.16 \mathrm{bc}$ \\
\hline $40 \mathrm{~cm}$ & $\mathrm{x}$ & $70 \mathrm{~cm}$ & $0.67 \mathrm{bc}$ & $0.21 \mathrm{~b}$ & $1.62 \mathrm{~b}$ & $5.19 \mathrm{bc}$ \\
\hline $60 \mathrm{~cm} \times \mathrm{x}$ & $40 \mathrm{~cm}$ & $0.74 \mathrm{~b}$ & $0.22 \mathrm{~b}$ & $1.71 \mathrm{~b}$ & $5.74 \mathrm{bc}$ \\
\hline $60 \mathrm{~cm}$ & $\mathrm{x}$ & $50 \mathrm{~cm}$ & $0.51 \mathrm{cde}$ & $0.16 \mathrm{bcd}$ & $1.12 \mathrm{c}$ & $5.69 \mathrm{bc}$ \\
\hline $60 \mathrm{~cm} \times \mathrm{x}$ & $60 \mathrm{~cm}$ & $0.57 \mathrm{bcd}$ & $0.17 \mathrm{bcd}$ & $1.13 \mathrm{c}$ & $4.92 \mathrm{bcd}$ \\
\hline $60 \mathrm{~cm} \times \mathrm{x}$ & $70 \mathrm{~cm}$ & $0.40 \mathrm{de}$ & $0.11 \mathrm{~d}$ & $0.83 \mathrm{de}$ & $3.88 \mathrm{cde}$ \\
\hline $80 \mathrm{~cm} \times \mathrm{x}$ & $40 \mathrm{~cm}$ & $0.50 \mathrm{cde}$ & $0.14 \mathrm{~cd}$ & $1.11 \mathrm{c}$ & $4.57 \mathrm{~b}-\mathrm{e}$ \\
\hline $80 \mathrm{~cm} \times \mathrm{x}$ & $50 \mathrm{~cm}$ & $0.52 \mathrm{~b}-\mathrm{e}$ & $0.16 \mathrm{bcd}$ & $1.08 \mathrm{~cd}$ & $3.00 \mathrm{de}$ \\
\hline
\end{tabular}


Influence of Plant Population Density on Growth and Yield of Lavender (Lavandula Anguistifolia L.) at Menagesha West Ethiopia

\begin{tabular}{|c|c|c|c|c|c|}
\hline \multicolumn{7}{|c|}{} & \multicolumn{3}{l|}{} \\
\hline $80 \mathrm{~cm} \quad \mathrm{x}$ & $60 \mathrm{~cm}$ & $0.38 \mathrm{de}$ & $0.11 \mathrm{~d}$ & $0.82 \mathrm{de}$ & $2.92 \mathrm{de}$ \\
\hline LSD & $70 \mathrm{~cm}$ & $0.34 \mathrm{e}$ & $0.11 \mathrm{~d}$ & $0.74 \mathrm{e}$ & $2.25 \mathrm{e}$ \\
\hline CV\% & & 0.22 & 0.067 & 0.27 & 2.36 \\
\hline
\end{tabular}

Means followed by the same letter within the same column are statistically no significant at $P<0.05$ according to least significant difference (LSD) test

Table5. Interaction effects of years with inter-row spacing on fresh flower oil yield and dry leaf yield per hectare

\begin{tabular}{|c|c|c|c|c|c|c|c|c|}
\hline Cropping years & \multicolumn{4}{|c|}{ Flower oil yield $\left(\mathrm{t} \mathrm{ha}^{-1}\right)$} & \multicolumn{5}{c|}{ Dry leaf yield $\left(\mathrm{t} \mathrm{ha}^{-1}\right)$} \\
\hline & \multicolumn{3}{|c|}{ Inter-row spacing } & \multicolumn{5}{c|}{ Inter spacing } \\
\hline & $40 \mathrm{~cm}$ & $60 \mathrm{~cm}$ & $80 \mathrm{~cm}$ & Mean & $40 \mathrm{~cm}$ & $60 \mathrm{~cm}$ & $80 \mathrm{~cm}$ & Mean \\
\hline 2016 & $0.669 \mathrm{~b}$ & $0.589 \mathrm{bc}$ & $0.448 \mathrm{~cd}$ & 0.66 & $1.59 \mathrm{~b}$ & $0.98 \mathrm{c}$ & $0.781 \mathrm{~d}$ & 1.12 \\
\hline 2017 & $0.94 \mathrm{a}$ & $0.521 \mathrm{bcd}$ & $0.427 \mathrm{~d}$ & 0.54 & $1.89 \mathrm{a}$ & $1.41 \mathrm{~b}$ & $1.10 \mathrm{c}$ & 1.47 \\
\hline Mean & 0.80 & 0.56 & 0.44 & & 1.74 & 1.20 & 0.94 & \multicolumn{5}{c|}{0.19} \\
\hline LSD 0.05 & \multicolumn{3}{|c|}{0.176} & \multicolumn{5}{c|}{18.3} \\
\hline CV\% & \multicolumn{3}{|c|}{29.6} & \multicolumn{5}{c|}{} \\
\hline
\end{tabular}

Means followed by the same letter within the same rows are statistically no significant at $P<0.05$ according to least significant difference (LSD) test;

\subsection{Dry Leaf Yield (t ha $\left.{ }^{-1}\right)$ and Flower Oil Yield $\left(\mathrm{kg} \mathrm{ha}^{-1}\right)$}

Dry leaf yield and flower oil yield of lavender were significantly $(\mathrm{P}<0.05)$ affected by the main effect of year, intra-row, inter-row spacing as well as the interaction of intra-row with inter-row spacing (Table 1).

The significantly higher dry leaf yields and flower oil yield were recorded from the combined spacing of $40 \mathrm{~cm} \times 40 \mathrm{~cm}$ intra-row and inter-row. These were followed by the dry leaf yield and flower oil yield obtained from the combined spacing of $40 \mathrm{~cm}$ inter-row with $50 \mathrm{~cm}, 60 \mathrm{~cm}, 70 \mathrm{~cm}$ intra-row and $60 \mathrm{~cm}$ inter-row with $40 \mathrm{~cm}$ intra-row spacing. The lowest dry leaf yields and flower oil yield were scored at the combined spacing of $70 \mathrm{~cm} \times 80 \mathrm{~cm}$ intra-row and inter-row respectively. The combination of $40 \mathrm{~cm}, 60 \mathrm{~cm} \& 80$ inter-rows spacing with the wider $(70 \mathrm{~cm}$ intra-row) spacing over the narrow (40cm intra-row) spacing dry leaf yield was decreased by $30.71 \%, 64.6 \% \% 68.5 \%$. In agreement with this result, Zigene et al. (2012) and Mishra et al. (2009) reported that rosemary, fresh leaf yield ha ${ }^{-1}$ was lower in wider spacing due to the accommodation of least number of plants in the one-hectare land.

\subsection{Above Ground Biomass and Oil, Leaf Yield}

The pooled mean analysis of variance showed that above ground biomass was significantly influenced by the main effect of intra-row and inter-row spacing. Significantly higher aboveground biomass was recorded in the second year than the first year. This could be due to the age of the plant that can develop more branch, leaf and stem contribute to have high aboveground biomass in second year. Maximum above ground biomass $\left(3.8 \mathrm{tha}^{-1}\right)$ and $\left(3.5 \mathrm{t} \mathrm{ha}^{-1}\right)$ were obtained from $40 \mathrm{~cm}$ intra-row and inter-row spacing respectively. Minimum aboveground biomass $\left(1.89 \mathrm{t} \mathrm{ha}^{-1}\right)$ and $\left(1.90 \mathrm{t} \mathrm{ha}^{-1}\right)$ were recorded from 70 intra-row and $80 \mathrm{~cm}$ inter-row spacing respectively. As the distance between row and within row, far part aboveground biomass per area was decreased due to the accommodation low number plant per area.

The main effect of intra-row and inter-row spacing were significantly affected oil leaf yield of Lavandula Angustifoila. Similarly, significantly higher oil leaf yield also obtained from the second year product than the first year. Maximum oil leaf yield $\left(13.5 \mathrm{~kg} \mathrm{ha}^{-1}\right)$ and $\left(14.3 \mathrm{~kg} \mathrm{ha}^{-1}\right)$ were obtained from $40 \mathrm{~cm}$ intra and $40 \mathrm{~cm}$ inter-row spacing. These closely followed by the oil leaf yield obtained from $50 \mathrm{~cm}$ intra and $60 \mathrm{~cm}$ inter-row spacing. Minimum oil leaf yield $\left(8.0 \mathrm{~kg} \mathrm{ha}^{-1}\right)$ and $\left(6.9 \mathrm{~kg} \mathrm{ha}^{-1}\right)$ were recorded from the wider spacing (Table 2). This result agreed with the report of Zigene et al. (2012) and Mishra et al. (2009) that showed increments of herbage yield and oil leaf yield of rosemary per hectare at closer spacing. The increment of oil yield at a higher density was also due to higher leaf yield/ha at higher density. 

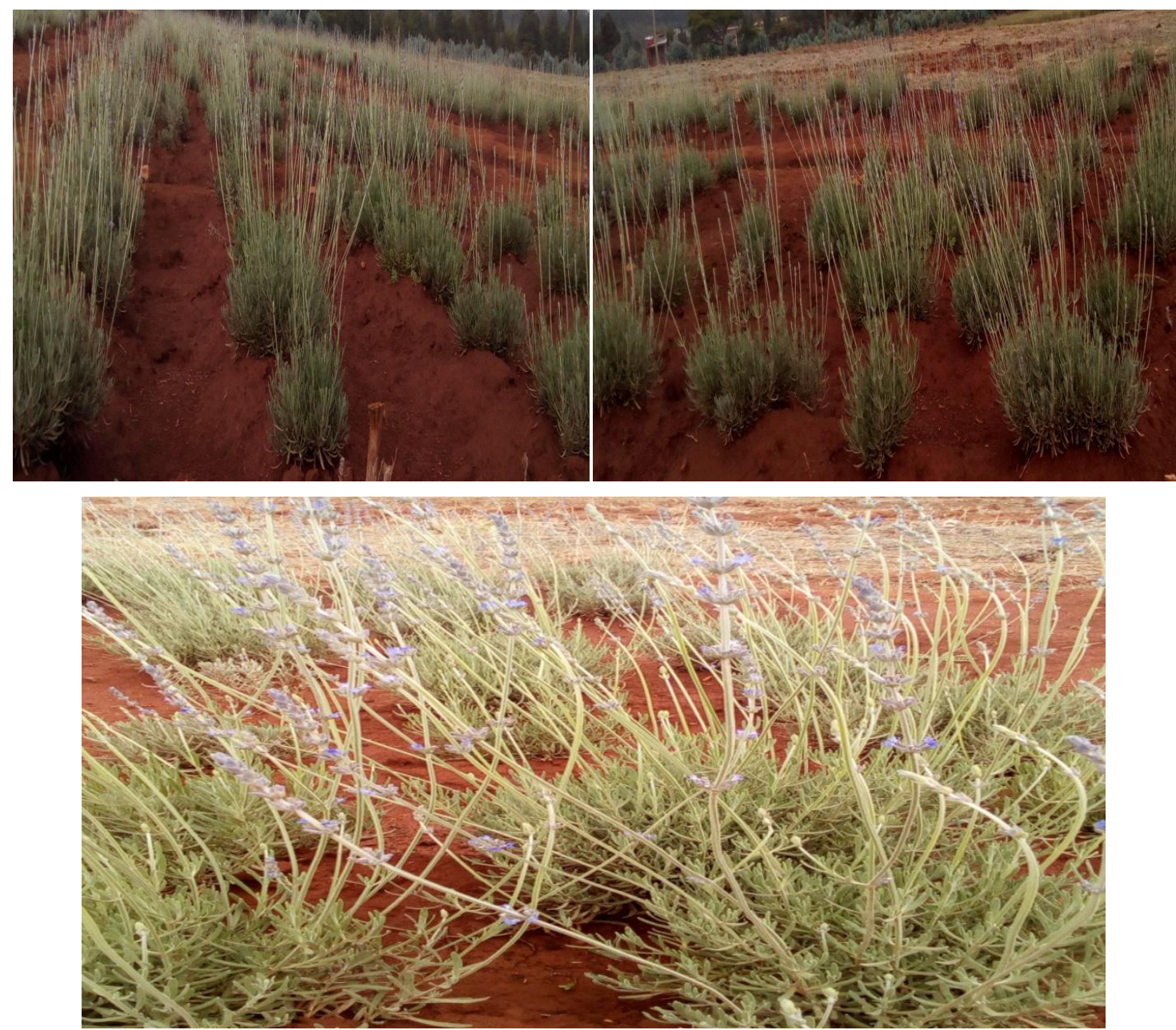

Fig. Field status during experimental period

\section{CONCLUSION}

After going through the results of the present experiment, selections of best inter and intra-row spacing helps to utilize the small land efficiently and intensively. Therefore the two consecutive studies showed that the high economic leaf yield $\left(2.34 \mathrm{tha}^{-1}\right)$, flower yield $\left(0.37 \mathrm{t} \mathrm{ha}^{-1}\right)$, flower oil yield $\left(10.3 \mathrm{~kg} \mathrm{ha}^{-1}\right)$ and leaf oil yield $\left(13.9 \mathrm{~kg} \mathrm{ha}^{-1}\right)$ was recorded from the combined spacing of $40 \mathrm{~cm}$ intrarow and $40 \mathrm{~cm}$ inter-row spacing. Thus the best combined intra-row and inter-row spacing for Lavandula angustifolia is $40 \mathrm{~cm} \times 40 \mathrm{~cm}$ to attain maximum yield under appropriate management conditions for Menagesha and Similar agro ecology.

\section{ACKNOWLEDGMENT}

We would like to acknowledge Crop Research Directorate, Wondo Genet Agricultural Research Center and Menagesha Rehabilitation Center- Cheshire Ethiopia for providing all the necessary facilities and support during the entire experimentation. Our sincere appreciation goes to Gizachewu Atinafu, Cherenet Tefera, Birara Tilahun, Zerihun Jonba, Berso me'eso, Bereket Tukkisa, and Alemitu Teka for providing all the necessary facilities and support during the field and laboratory works.

\section{REFERENCES}

[1] Adam k., Lavender Production, Products, Markets, and Entertainment Farms. Sustainable Agriculture Information Service, Appropriate Technology Transfer for Rural Areas (ATTRA) (2006).

[2] Whiriskey J and McCarthy P (eds). Lavender Production Fact sheet (2006) No. 52.

[3] Chatterjee SK., Cultivation of medicinal and aromatic Plants in India- A commercial approach. Actacta Hort. (ISHS), 576: 191-202, (2002).

[4] Badi HN, Yazdani D. Ali SM. and Nazari F., Effects of spacing and harvesting time on herbage yield and quality/quantity of oil in thyme, Thymus vulgaris L. Ind Crops Prod. 19: 231-236, (2004). 
[5] Hall AE., Physiological ecology of crops in relation to light, water, and temperature. In: carroll CR, vandermeer JH, Rosset PM, editors, Agroecology. New York (NY); McGraw-Hill; p 191-234 (1990).

[6] Tadesse N, Gebere A, Lulie B , Hordofa M., Influence of plant population density on growth and yield of Stevia (Stevia rebaudiana Bertoni L.) at Wondo Genet South Ethiopia. Acad. Res. J. Agri. Sci. Res. 4(6): 321-329(2016).

[7] Beemnet M, Zewdinesh D., Zinash T., Solomon A., Biniyam Y., et al. Yield and yield components of rose-scented geranium (Pelargonium graveolens) as influenced by plant population density in Ethiopia. Medicinal and Aromatic Plant Science and Biotechnology 2 (1), 60-68 (2012).

[8] Zewdinesh D, Bizuayehu T. \& Daniel B., Leaf, Essential Oil and Artemisinin Yield of artemisia (Artemisia annua L.) as influenced by harvesting age and plant population density. World Journal of Agricultural Sciences 7 (4): 404-412(2011).

[9] Zigene ZD, Kassahun BM. \& Ketaw TT., Effects of Harvesting Age and Spacing on Leaf Yield and Essential Oil Yield of Rosemary (Rosmarinus officinalis L.). In: Zigene ZD (Ed) Plant science and biotechnology in Ethiopia. The African Journal of Plant Science and Biotechnology 6 (Special Issue 1), (pp 9-12) (2012).

[10] Mishra AC, Negi KS, Shukla HY, Sharma AK., Effect of spacing on the performance of rosemary (Rosemarinus officinalis L.) blue flowered genotype (NIC-23416) in mid hills of Uttarakhand under rain fed conditions natural product Radiance 8 (5), 528-531(2009).

Citation: Nebret Tadesse, "Influence of Plant Population Density on Growth and Yield of Lavender (Lavandula Anguistifolia L.) at Menagesha West Ethiopia” International Journal of Research Studies in Agricultural Sciences (IJRSAS), 2019; 5(11), pp. 1-7, http://dx.doi.org/10.20431/2454-6224.0511001

Copyright: (C) 2019 Authors. This is an open-access article distributed under the terms of the Creative Commons Attribution License, which permits unrestricted use, distribution, and reproduction in any medium, provided the original author and source are credited. 